\title{
Between the processes of strengthening and weakening of the Family Health Strategy
}

\author{
Entre os processos de fortalecimento e de fragilização da Estratégia Saúde da Família
}

Entre los procesos de fortalecimiento e de debilitamiento de la Estrategia Salud de la Familia

\section{Regina Stella Spagnuolo', Silvia Cristina Mangini Bocchi'}

\author{
' Universidade Estadual Paulista "Júlio de Mesquita Filho", Faculdade de Medicina de Botucatu, \\ Departamento de Enfermagem. Botucatu-SP, Brasil.
}

Submissão: 15-06-2012 Aprovação: 15-05-2013

\begin{abstract}
This was a qualitative study with the purpose of designing a meta-model for the work process of the Family Health Strategy (FHS) team. It was based on the experience of six sample groups, composed of their members (physicians, professional nurses, dentists, dental assistants, licensed technical nurses and community health agents) in a city in São Paulo state, Brazil, totaling 54 subjects. Six theoretical models emerged from non-directive interviews. These were analyzed according to Grounded Theory and submitted to the meta-synthesis strategy, which produced the meta-model "between the processes of strengthening and weakening of the FHS model: professional-team-community reciprocity as an intervening component". When analyzed in light of the Theory of Complexity (TC), it showed to be a work with a vertical and authoritarian tendency, which is largely hegemonic in the tradition of public health care policies.
\end{abstract}

Key words: Family Health Program; Public Health; Non-Linear Dynamics; Qualitative Research.

\section{RESUMO}

Pesquisa qualitativa, em que se elaborou um metamodelo do processo de trabalho da Estratégia Saúde da Família (ESF), a partir da experiência de seis grupos amostrais: médicos, enfermeiros, cirurgiões dentistas, auxiliares de cirurgião dentista, auxiliares de enfermagem e agentes comunitários de saúde, de um município do interior paulista, perfazendo 54 atores. Das entrevistas não diretivas, analisadas segundo a Teoria Fundamentada nos Dados, emergiram seis modelos teóricos, os quais foram submetidos à estratégia de metassíntese, produzindo o metamodelo "entre os processos de fortalecimento e de fragilização do modelo ESF: reciprocidade profissional - equipe - comunidade como componente interveniente". Analisado à luz da Teoria da Complexidade (TC), revelou-se um trabalho de tendência verticalizada e autoritária, largamente hegemônico na tradição das políticas públicas de saúde.

Descritores: Programa Saúde da Família; Saúde Pública; Dinâmica não Linear; Pesquisa Qualitativa.

\section{RESUMEN}

En esta investigación cualitativa se elaboró un metamodelo del proceso de trabajo de la Estrategia Salud de la Familia (ESF) con base en la experiencia de seis grupos de muestras: médicos, enfermeros, cirujanos dentistas, auxiliares de cirujano dentista, auxiliares de enfermería y agentes comunitarios de salud de un municipio del interior de São Paulo, con un total de 54 actores. De las entrevistas no directivas, analizadas según el Muestreo Teórico, emergieron seis modelos teóricos que se sometieron a la estrategia de meta síntesis y produjeron el metamodelo "entre los procesos de fortalecimiento y de debilitamiento del modelo ESF: reciprocidad profesional - equipo - comunidad como componente interviniente". Analizado a la luz de la Teoría de la Complejidad (TC) se reveló un trabajo de tendencia vertical y autoritaria, largamente hegemónico en la tradición de las políticas públicas de salud.

Palabras clave: Programa Salud de la Familia; Salud Pública; Dinámica no Lineal; Investigación Cualitativa.

\section{AUTOR CORRESPONDENTE Regina Stella Spagnuolo E-mail: rstella@fmb.unesp.br}




\section{INTRODUCTION}

The reorganization process in the Brazilian health care system has taken place in consonance with Primary Health Care $(\mathrm{PHC})$, based on international models and experiences, but respecting the specificities of the Brazilian health scenario and social determinants.

International studies have shown PHC to be a promising model for the access to and provision of integrated health care actions, and, thus, producing indicators that have ensured better quality of life for the population ${ }^{(1)}$.

This impact can be perceived in South American countries, where human development has improved as a result of reforms undertaken by their health care systems.

Based on successful isolated experiences in Brazilian cities, the Health Ministry created the Family Health Program (FHP) in 1994 as a structural strategy for PHC, and to modify the health care provision model ${ }^{(2-3)}$. At the time of implementation, a great deal of discussion identified a concern that the strategy could be influenced by public policies of a vertical character, with little space for local contextualization. Additionally, the orientations for the implementation of the program were similar to recommendations from international organizations that defended a selective PHC with packages of restricted programs and focused coverage ${ }^{(4)}$.

According to the PHC guidelines, in the same decade, Brazil began to use the term Primary Care to characterize health care provision at the first level, which is defined as a set of actions of individual and collective character targeted at promoting health, disease prevention and the treatment and rehabilitation of injuries.

Within the "primary health care policies", this level also comprises the family health units (FHU), with teams formed by at least one physician, one nurse, one dentist, licensed technical nurses and community health agents. These professionals must work in communities within a demarcated territory and with a delimited population.

These teams are expected to be capable of providing integrated (biopsychosocial, preventive, curative, rehabilitative) and longitudinal care (follow-up of the same individuals over time), supported by the Family Health Support Centers (FHSC), which include psychologists, social workers and other professionals.

This level of care provision must also coordinate the flow of information as well as the flow of users requiring other care types provided by the "health care network", which offers the necessary resources and concentrates technology in a denser fashion, such as hospitals and specialty outpatient units ${ }^{(5)}$.

This scenario places FHS as the main strategy for making $\mathrm{PHC}$ feasible, through the proposal of changing the rationality of care provision based on the work of a multiprofessional team.

Despite the advancement achieved, FHS still faces challenges to become consolidated as the health care model in some Brazilian cities, where its implementation occurred with great enthusiasm both by city managers and by multiprofessional teams. However, as time passed, they became immersed in work processes that were similar to outmoded care provision models and, therefore, lost their initial characteristics ${ }^{(6)}$.

In light of the relevance of the context of implementation and of the challenges experienced within the FHS model, a question raised was, "how do multiprofessional health team members understand the work process within the FHS?"

By seeking answers to such a question, and in order to understand the present scenario of FHS as a health care model, this study aimed to design a meta-model of the work of the multiprofessional team in the FHS, based on the experience of six sample groups composed of its members.

\section{METHOD}

This was a qualitative study, which was approved by the Research Ethics Committee, of 023/08 CEP/Botucatu-SP, that was conducted after the participants had signed the terms of free and informed consent form. Data were collected from February to March of 2008, by non-directive interviews with six sample groups formed by members of the FHS multiprofessional team in a city in São Paulo state, Brazil: physicians, (11), nurses (08), dentists (07), dental assistants (07), licensed technical nurses (11) and community health agents (10). The interviews were taped, fully transcribed and analyzed according to the Grounded Theory methodological framework ${ }^{(7)}$, comprising the following phases: open, axial and selective coding. Such a framework allowed for the development of six theoretical models from the information obtained in each sample group, resulting from systematic and comparative analyses until theoretical saturation was obtained; that is, when the information began to repeat, new data were not found, and the unveiled theoretical model was shown to be capable of explaining the data. In order to perform the meta-synthesis of the six theoretical models stemming from the team members' experiences, meta-study resources were used. Such a method allows for the performance of analyses of theories, methods and results of qualitative studies and synthesizing them ${ }^{(8)}$. The meta-synthesis enabled us to recall the ideas that were separated or deconstructed in the analytical processes. It represented the creation of a new interpretation of a phenomenon responsible for the data, methods and theories by means of which the phenomenon was studied. This strategy allowed for the development of a meta-model (Figure 1) that represented the interactional experience of the FHS multiprofessional team, which was validated by the subjects participating in this study, and later analyzed in light of the TC theoretical framework, according to Wheatley ${ }^{(9-10)}$; Prigogine ${ }^{(11)}$; Briggs \& Peat ${ }^{(12)}$. To these authors, accepting the importance of interactions and the constant change among subjects and situations increasingly enables us to act in conditions of complexity, that is, to destructure ourselves, to leave pre-determined and hegemonic conducts, to observe the network formed and to promote the necessary changes to respond to new demands from the FHS model.

\section{RESULTS AND DISCUSSIONS}

The meta-synthesis of the six theoretical models stemming from the experience of the multiprofessional team members 
enabled the construction of a meta-model named: between the processes of strengthening and weakening of the FHS model: professional-team-community reciprocity as an intervening component (Figure 1).

In team work, the reciprocity between professionals, the team and the community was shown to be the essence of FHS work, and it was understood as exchanges and retributions that took place between the management, the team and the community realms.

The study by Gouldner ${ }^{(14)}$ showed the existence of a mental representation of knowledge on reciprocity, which interweaved concepts observed in the context of team work, such as: donor, receptor, retribution, obligation, creditor, and debtor.

The meta-model proved capable of representing and explaining the interactions and reciprocity among the team members, and with the work process, by signaling that the movement that maintained the team in FHS resulted from such members' enthusiasm in light of the possibility of a new praxis in health care.

To them, it meant the opportunity to move away from a type of work that was solitary, task-based and fragmented, and that no longer met their needs, in order to find an opportunity of experiencing a health care modality based on team work and focused on the community and its family groups, with potentialities for resignification.

Hence, these professionals found the possibility of providing comprehensive health care - their ideal - and integrated themselves into teamwork, which provided them with the social visibility of the profession, since the community and their peers acknowledged their praxis. Thus they experienced professional-team-community reciprocity, which was only achieved when they realized that their ideal of working in comprehensive health care had been realized.

Such process culminated in the strengthening of team work and, consequently, in the FHS model, as it established new bonds with the team and the community.

However, as time passed, these professionals became unmotivated with FHS work, due to lack of psychological, logistical and structural support from municipal management for coping with so many problems and conflicts arising in the community, families and within teamwork.

Additionally, they unveiled resentment in relation to health education institutions, as they could not find support for a more generalist education, which is necessary for this health care model, in their undergraduate, specialization and graduate curricular components. In this scenario, they did not realize the comprehensive care that was so idealized, and they became frustrated with the FHS model, thus losing the social visibility of the profession and failing to experience the professional-community-team reciprocity as the essence of their experiences.

The professionals showed their intention to not "stay" in this health care model and "broke away" psychically and emotionally from this type of work. Such movement weakened the bond constructed between the team and the community, and as a consequence, weakened the FHS care model, making it more susceptible to failure.

Figure 1 - Theoretical Meta Model: Between the processes of strengthening and weakening of the Family Health Strategy Model: municipal management - educational institutions as intervening components.

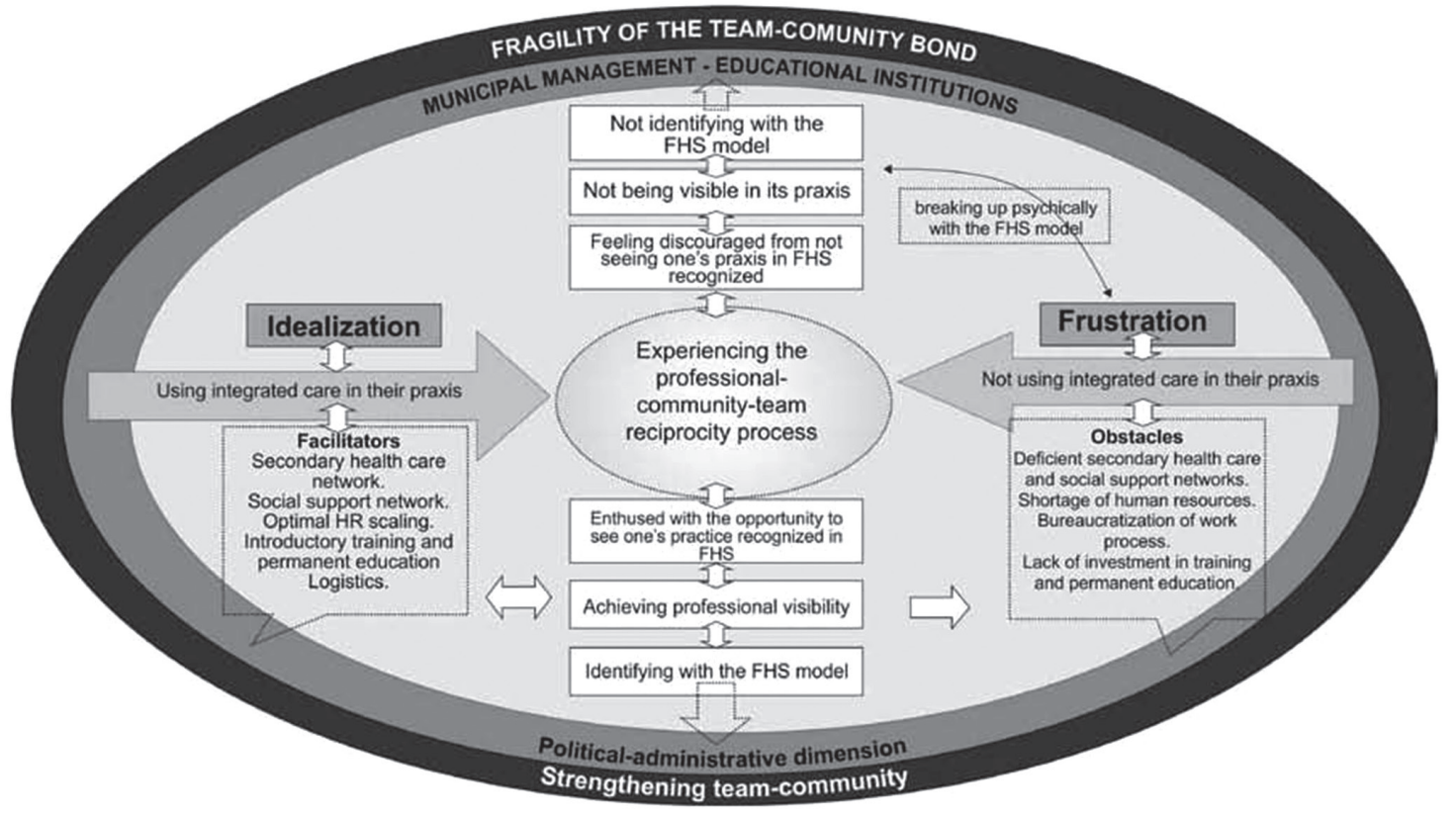


To TC, a team with an open system is in dynamic balance because it continuously assimilates and adapts to chang$\mathrm{es}^{(9,11,13)}$. To that end, facilitating elements in FHS work were assessed, such as having a support network from the secondary health care level and social support as constructs from a network that strengthened such relationships and work.

The international literature reported that the quality of such relationships and that of a team's interactional processes were more important during life than the very structure of a service, that is, the focus of action in organizations must be on people, their relationships and worldview. This fact affects the team, which, on the other hand, affects the quality of relationships ${ }^{(9-12)}$.

They also facilitated work by satisfactorily scaling the staff according to each team's needs and to the local reality, associated with permanent health education processes.

On the other hand, elements were found that the team considered to be hindering factors, since they reinforced mechanical behavior, and creative changes did not occur, which prevented the social visibility of the profession.

As regards municipal management, the results showed that the team resented the lack of internal support, that is, of local support and understanding, both in the psychological and structural realms.

Team members did not count on a secondary support network or on a social health care network; hence, they felt overloaded, frustrated, unmotivated and disillusioned in relation to the FHS ideology.

The studies by Wheatley ${ }^{(9-10)}$; Prigogine ${ }^{(11)}$ and Brigs \& Peat ${ }^{(12)}$ showed that, in a non-linear relationship, complex effects may originate from simple causes. In general, dynamic systems such as a team are not linear, and they may become self-disorganized. And self-organization does not impose independence of that the team's behavior from the environment. In fact, the team needs the environment because the rules followed by agents, among other things, are responses to environmental stimuli. For this reason, changing the environment is a way by which a team's behavior can be changed, that is, it facilitates the processes of change within the team.

It is also necessary to discuss the constitution of social networks, which is one of the most important current strategies for implementing forms of communication, knowledge production and collective actions among people.

Thinking and performing in the form of networks is, therefore, a stimulus for the realization of integrated care. Each member of the team-management-community can function as a larger linking knot for collectively understanding territorial problems, thus being able to change reality.

Large restructuring, or processes of change, can be generated from small actions; this can trigger what is known as the butterfly effect ${ }^{(12)}$.

It is noteworthy that many of these professionals had left other work scenarios because they considered them to be mechanistic and fragmented, often solitary, in order to move towards the FHS proposal, hoping to realize the praxis of integrated care supported by a network.

However, when they found the work process in the functional care modality, which is partitioned, reductionist, and which lacks continuing education, they became discouraged.

Another hindering factor was the deficiency in continuing education in health care services. It is important in the team's ability to form a dynamic system because, when it is well operationalized, it generates significant learning that leads to change in professional practice ${ }^{(15)}$.

With this regard, managers must seek partnerships with local educational networks (universities) in order to design projects for implementing the Permanent Committee for TeachingService Integration (PCTSI), proposed by Resolution 1.996, dated August 20, 2007 $7^{(15)}$.

Satisfactorily, the study showed the need to perform research leading to a model that can help scale the personnel working in primary care-FHS so that intuitive data are changed into scientifically based information. This also holds true because the issue related to human resources $(\mathrm{HR})$ in health care is not only related to financial aspects and the Fiscal Liability Law, but also to health care management.

An information system that shows the production-professional-service of actions, relating time to care provision complexity, is necessary, since it will enable the planning of such scaling.

The Health Ministry, in turn, has issued resolutions ensuring a national primary care policy and the implantation of Primary Care Units for the FHS model, and it has accredited municipalities to receive grants for Support Centers for Family Health (SCFH) ${ }^{(16)}$. Cities, in turn, must be attentive to such resolutions and become organized for their operationalization.

Hence, in order for team members to experience reciprocity among themselves and with the community, in order for comprehensive care to materialize and in order for professionals to become more visible, the work process must move towards more dynamics contours, in the form of networks and with support from the political and administrative realms of educational institutions, thus enabling the strengthening of bonds among team members, and between team members and the community.

It is this process that opens spaces for uncertainty, unpredictability and creativity, thus subsidizing planning grounded in scenarios, with many possibilities of self-organization ${ }^{(13)}$.

As regards educational institutions, TC can be presented to undergraduate students, not as another discipline in the academic and Cartesian world, but as a possibility of reorganizing the fragmented thought of students, who, as a rule, come to university well trained in the linear view of knowledge production.

The literature confirmed our findings by showing the evidence of divergence between professional education and reality. Knowledge is transmitted in a separated, divided and compartmentalized fashion in educational units (including universities).

However, realities or problems have increasingly become multidisciplinary, cross-sectional, global and planetary. Contexts, global and multidimensional scenarios become invisible ${ }^{(17)}$.

The acknowledgment of the non-linearity concept, brought by the Theory of Complexity, in the process of interprofessional education, provides the development of an environment that promotes creativity in work practices, encourages interactions, innovations and personal responsibility ${ }^{(18)}$. 
Even though universities have given priority to a generalist education in health care professions in the last few years, they still face the critical knot of education when, in their praxis, they find reductionist professors and professionals who do not approach patients in an comprehensive manner, but only refer them to specialists.

This attitude by educators and professionals is also part of the view of a mechanistic and reductionist world in which we have been immersed for more than three centuries.

In the view of complexity, a team was presented that was being held to a Cartesian and fragmented paradigm of well-being and sought to control and predict its members' actions, supported by predictable behaviors and relationships of little freedom to create and change.

Such a team does not recognize itself as a living, dynamic and adaptive system, because it does not develop new patterns of order and does not know the unequivocal power that its members have to relate among themselves and enable new events daily by changing their practices, even after the early moments of FHS implantation as a constant development.

When taking the developments of contemporary science as a fundamental, TC recovers the observing subject by analyzing the impossibility of excluding him and values the role played by the contingency of such comprehension.

It also proposes living with crises, unveiling what is hidden, that is, without overcoming all the aspects of the old and questioned way of performing in health care and without questioning the order of such praxis, a new order will not be established, and new things will not emerge.

Additionally, complexity offers itself as a potential articulator of differences and of those who are different, which, from other perspectives, is difficult to articulate ${ }^{(19)}$.

\section{CONCLUSION}

Using Grounded Theory and the Meta-study as a methodological basis, and TC as a theoretical framework, enabled us to understand the core of the experience shown by multiprofessional team members working for the FHS model, which was the professional-community-team reciprocity process. Experiencing such reciprocity was the internal interactive reality among a team's members, while it was the external interactive reality between the team and the community, municipal management and educational institutions. It affected those realms, and they affected it. This was essentially a complex problem that maintained or averted professionals from the FHS model. This study has given visibility to the forms of resistance in this model, which had a vertical and authoritative tendency and was largely hegemonic in the tradition of public health care policies. Recognizing such forms of resistance and having strategies to change them so as to foster dialogue, better relationships, power and responsibility sharing, and decentralization are challenges to Primary Care advancement in its participative proposal identified in the FHS model.

If the important aspect is to potentiate efforts that can boost changes towards the construction of a new paradigm in health care, TC seems to shed light on such issues, and it can result in important improvements in understanding team members' interactional relationships around Family Health as a major strategy in Primary Care.

It is believed that one of the main contributions discovered through the meta-model was the possibility for it to become a guiding reference in the design of service evaluation instruments, as well as to show gaps and possible strategies for FHS reorganization with the purpose of strengthening Primary Care.

\section{REFERENCES}

1. Starfield B, Shi L. Policy relevant determinants of health: an international perspective. Health Policy 2002;60(3):201-218.

2. Giovanella L, Escorel S, Mendonça MHM. Porta de entrada pela atenção básica? Integração do PSF à rede de serviços de saúde. Saúde Debate 2003;27(65):278-289.

3. Ministério da Saúde (Brasil). Portaria nº. 648, de 28 de março de 2006. Aprova a Política Nacional de atenção básica, estabelecendo a revisão de diretrizes e normas para a organização da atenção básica para o programa Saúde da família (PSF) e o programa agentes comunitários de saúde(PACS). Diário Oficial da União 26 mar 1998;Seção 1.

4. Fundação Oswaldo Cruz. Estudos de Caso sobre implementação da estratégia saúde da família em quatro grandes Centros Urbanos Escola Nacional de Saúde Pública Sergio Arouca. Relatório final: 2011. Belo Horizonte: FIOCRUZ; 2011.

5. Ministério da Saúde. Política Nacional de Atenção Básica. Brasília, DF: O Ministério; 2006.
6. Spagnuolo RS. Entre os processos de fortalecimento e fragilização do modelo ESF: gestão municipal - órgãos formadores como componentes intervenientes Botucatu. Tese [Doutorado em Saúde Coletiva] - Faculdade de Medicina de Botucatu da Universidade Estadual Paulista; 2010.

7. Strauss AL, Corbin J. Pesquisa Qualitativa. Técnicas e procedimentos para o desenvolvimento de teoria fundamentada. 2. ed. Porto Alegre: Artmed; 2008.

8. Paterson BL, Thorne SE, Canam, C, Jillings C. Meta-Study of qualitative health research: a practical guide to meta-analysis and meta-synthesis. London: Sage Publications; 2001.

9. Wheatley MJ. Liderança e a nova ciência: aprendendo organização com um universo ordenado. São Paulo: Cultrix; 1992.

10. Wheatley MJ. Liderança para tempos de incerteza: a descoberta de um novo caminho. São Paulo: Cultrix; 2005.

11. Prigogine I. O fim das certezas: tempo, caos e as leis da natureza. São Paulo: UNESP; 1996. 
12. Briggs J, Peat FD. A sabedoria do caos: sete lições que vão mudar sua vida. Rio de Janeiro: Campus; 2000.

13. Morin, E. Da necessidade de um pensamento complexo. In: Martins FM, Silva JM, organizadores. Para navegar no século XXI/21: tecnologias do imaginário e cibercultura. 2. ed. Porto Alegre: Sulina; 2000.

14. Gouldner AW. The norm of reciprocity: a preliminary statement. Am Sociological Rev 1960 25(2);161-178.

15. Ministério da Saúde (Brasil). Portaria $n^{\circ}$. 1.996, de 20 de agosto de 2007. Dispõe sobre as diretrizes para a implementação da Política Nacional de Educação Permanente em Saúde e dá outras providências [portaria na internet]. Diário Oficial da União 22 ago 2007 [acesso em 22 fev 2010];Seção 1. Disponível em: http://portal.saude.gov.br/ portal/arquivos/pdf/portaria1996.pdf
16. Ministério da Saúde (Brasil). Portaria n² 2.447, de 14 de outubro de 2009. Credencia Municípios a receberem o incentivo financeiro aos Núcleos de Apoio à Saúde da Família - NASF [portaria na internet]. Diário Oficial da União 30 jun 2008 [acesso em 14 jul 2010];Seção 1. Disponível em: http://bvsms.saude.gov.br/bvs/saudelegis/gm/2009/ prt2447_14_10_2009.html

17. Fálcon GS, Erdmann AL, Meirelles BHS. A complexidade na educação dos profissionais para o cuidado em saúde. Texto \& Contexto Enferm 2006;15(2):343-51.

18. Cooper $\mathrm{H}$, Spencer-Dawe E. Involving service users in interprofessional education narrowing the gap between theory and practice. J Interprof Care 2006;20(6):603-17.

19. Moreno JC. Sentidos y derivaciones de la complejidad. In: UNESCO. Manual de Iniciación Pedagógica Al Pensamento Complejo. Colômbia: 2002. p. 121-130. 